\title{
The Effect of Quality of Work Life (QWL) on Job Satisfaction and Organization Citizenship Behavior (OCB) (A Study of Nurse at Numerous Hospitals in Malang, Indonesia)
}

\author{
Ika Ruhana ${ }^{a} *$, Endang Siti Astuti a, Hamidah Nayati Utami ${ }^{\text {a }}$, Tri Wulida Afrianti a \\ ${ }^{a}$ Brawijaya University, Malang, East Java, Indonesia
}

\section{ARTICLE INFORMATION}

\section{Article history:}

Data submission : May 19, 2019

$1^{\text {st }}$ revision: June 10,2019

Accepted: July 16, 2019

Available online: December 12, 2019

Keywords: Quality of work life (QWL), Job Satisfaction and Organization Citizenship Behavior (OCB)

\section{ABSTRACT}

Good QWL is needed by the organization, in order to achieve organizational goals and increase satisfaction for employees, $\mathrm{n}$ this study is job satisfaction and OCB for nurses.The purpuse of the study is to analyse and describe the influence of QWL on job satisfaction, the effect of QWL on OCB and the effect of job satisfaction on OCB. This research was conducted in four general hospitals that have type A, B, C and D. The samples in this study were nurses in the four hospitals. Based on the sampling technique obtained a sample of 175 respondents. The main instrument in collecting data by distributing questionnaires. The general hospital that is the location of this study is the Saiful Anwar Regional General Hospital (RSSA) located in Malang City with type A, Persada Hospital located in Malang city with Type B, Karsa Husada General Hospital (RSUKH) in Batu City with Type C and Madinah Islamic Hospital in Kasembon Malang Regency with Type D. The analysis technique used was descriptive analysis and inferential analysis with GSCA. The results of the descriptive analysis showed that nurses' QWL was perceived as neutral by nurses. Job satisfaction was perceived as agreed by nurses and OCB responded in agreement by the nurse. The results of hypothesis testing using GSCA shows that QWL has a positive and significant effect on job satisfaction, QWL has a positive and significant effect on OCB and job satisfaction has a positive and significant effect on OCB. Advice that can be given to the hospital is to further improve the QWL of nurses, especially those relating to compensation indicators because compensation is perceived as neutral by nurses, especially with the provision of fair and adequate compensation. the hospital must pay more attention to working conditions especially related to a healthy physical environment. Satisfaction with payroll is perceived as neutral by nurses, especially related to satisfaction with the salary and benefits provided by the hospital. Satisfaction with promotion also needs to be improved again, especially with regard to promotion opportunities and the provision of information about promotion opportunities. Nurse OCB was perceived as agreed by the nurse. Therefore OCB nurses are good, so they can be maintained or improved again.

2019 FIA UB. All rights reserved.

\section{Introduction}

Increasing QWL can increase employee productivity and satisfaction. Improving employees' QWL is a prerequisite to increase their organizational productivity.
High OWL organizations achieve better productivity and become highly competitive. Positive results of QWL include reduced absenteeism, lower turnover and improved employee iob satisfaction (Meibel et al., 2013). Sirgy et al., 2001 describe QWL refers to a

* Corresponding author. Tel.: +62-852-3585-1699; e-mail: ika_r_fia@ub.ac.id 
person's subiective perception of his/ her work and the total working environment such as the compensation and development opportunities. QWL includes aspects of work-related life such as wages and hours, work environment, benefits and services, career prospects and human relations, which is possibly relevant to worker satisfaction and motivation (Hasanmoradi, 2011).

QWL is much broader and more diverse than organizational development, inensuring adequate and fair compensation, safe and healthy working conditions, opportunities forpersonal growth and development, satisfaction of social needs at work, protection of employee rights, compatibility between work and nonwork responsibilities, and the social relevance ofworklife (Walton, 1975).

Research from Hasanmoradi (2011) showed that there was a positive and significant effect of QWL on job satisfaction. The implementation of the QWL program can improve satisfaction for employees. Job satisfaction is an emotional response/ feeling satisfied employees about various aspects of their work (Luthans, 2005). QWL not only affects job satisfaction but satisfaction also exists in other life domains such as family life, social life, financial life, and so on (Sirgy et al., 2001). There have been many studies conducted relating to the impact/ influence of QWL on employee satisfaction, as done by Sirgy (2001), Muftah and Lafi (2011), Hasanmoradi (2011), Tabassum (2012), Gayathiri and Ramakrishnan (2013), the results of which show significant influence between QWL and job satisfaction.

QWL has a significant effect on OCB. Based on the opinion of Sundaray et al. (2010), one of the results of QWL is performance/ performance. In this study to measure performance using OCB variables. $\mathrm{OCB}$ is extra-task behavior/ extra role performance/ contextual performance (Sonnenteg, 2000). Research conducted by Kashani (2012), Nair (2013), Kasraie (2014) which aims to determine the relationship between QWL to OCB, the results show that there is a significant relationship between QWL and OCB.

Job satisfaction has a significant effect on OCB. Job satisfaction is related to OCB. Spector (1997) states that an employee who has a high job satisfaction rating correlates with positive OCB behavior, namely timely, altruism and compliance. Based on the results of previous studies that provide results are not the same, then in this study trying to reexamine the influence between these variables, namely the influence of QWL on job satisfaction, the effect of QWL on OCB and the effect of job satisfaction on OCB.

\section{Theory}

\subsection{Quality of Work Life (QWL)}

The QWL is a multidimensional construct, made up of a number of interrelated factors that need careful consideration to conceptualize and measure (described from European Foundation for the Improvement of Living Conditions 2002). Nanjundeswaraswamy and
Swamy (2013 associated QWL with iob satisfaction, jobinvolvement, motivation, productivity, health, safety, job security, competence development and balance between work and non-work life. Definition QWL from Rethinam and Ismail (2008) is amulti-dimensional construct, made up of a number of interrelated factors that need careful consideration to conceptualize and measure.

\subsection{Job satisfaction}

Evans, (2001) defined iob satisfaction as a positive emotional state resulting from the appraisal of one's job situation and is linked with the characteristics and demands of one's work. Job satisfaction is defined as an employee's level of positive effect towards job or job situation that enhances quality of work life (Rethinam and Ismail, 2008). Luthans (2005) defined job satisfaction as pleasurable or positive emotional state that resulting from the appraisal of job or job experience. Job satisfaction is a result of employee " $\mathrm{s}$ perseption from their job.

Ivancevich \& Matteson, 2002; Spector 1997, defined job satisfaction as an individual's total feeling about their job and the attitudes they have towards various aspects or facets of their job.

Indicators used to measure job satisfaction are satisfaction with work, satisfaction with payroll, satisfaction with promotion, satisfaction with supervisors, satisfaction with coworkers.

\section{3. $O C B$}

Bateman \& Organ (1983) define Organizational Citizenship Behavior (OCB) as some extra job related behaviors which go above and beyond the routine duties prescribed by the employee's iob descriptions. Organ, (1983) as the pioneer of extra role behavior and introduces the concept of OCB. Based on opinion from Organ (1988), OCB is defined as work-related behaviours that are discretionary, not related to the formal organisational reward system, and, in aggregate, promote the effective functioning of the organisation.

Organ (1988) identify five dimensions of OCB are Courtesy, Civic virtue, Sportsmanship, Altruism, and Conscientiousness. Altruism refers to is the behavior shown by wanting to help others. Courtesy refers to $\mathrm{s}$ shown by being polite towards others, safeguarding the rights of others.Sportsmanship is shown by the attitude of not easily complaining about the conditions at work. Civic virtue refers to an active involvement in the organizational activities.

\subsection{QWL and job satisfaction}

Walton (1975) states: stated that dissatisfaction in work is a condition that cannot be avoided by workers, frustration condition, boredom, disappointment, will be a problem for individuals and organizations and and will affect life in the organization. Ruzevicius (2007) and Tabassum (2012) states that QWL affects employee satisfaction. Employees with high QWL will be more productive and effective, because the QWL program, 
carried out by the organization can improve employee morale and organizational effectiveness (Tabassum, 2012). This shows that QWL is considered capable of increasing the participation and contribution of organizational members or employees towards the organization.

The results of previous studies indicate a relationship between QWL and satisfaction, where QWL has a positive and significant impact on job satisfaction. Several studies have been conducted related to the impact/ influence of QWL on employee satisfaction, as performed by Sirgy (2001), Saad et al. (2008), Muftah and Lafi (2011), Hasanmoradi (2011), Tabassum (2012), Gayathiri and Ramakrishnan (2013).

Previous research on the effect of QWL on job satisfaction showed different results by Saad et al. (2008) and Rubel and Kee (2014). In this study tried to reexamine the influence of QWL on job satisfaction

\section{4. $Q W L$ and $O C B$}

QWL is an effort to improve organizational culture that supports employee growth and development. Values in QWL including meeting employee needs (investment in people) are considered as important in strategic planning that leads to organizational efficiency (Kashani, 2012). High QWL is very important for organizations to attract and retain workers (Kasraei, et al., 2014). OCB is a behavior which one of them is shown by voluntary action to help colleagues in carrying out their duties. Several studies have been conducted to connect QWL with OCB. The research was conducted by: Sofiah et al. (2014), Kashani (2012), Nair (2013), Tehran et al. (2013) and Kasraie et al. (2014). The results show the influence of QWL on OCB. The study conducted by Kashani (2012) showed rather different results, the results showed that all $\mathrm{OWL}$ variables were at different levels in influencing OCB and there was no significant relationship between demographic characteristics with QWL and OCB.

\subsection{Job satisfaction and $O C B$}

Locke (1976) defined job satisfaction as "a pleasurable or positive emotional state resulting from the appraisal of one's job or job experiences". Research abaut the affect job satisfaction on OCB showed defferent results.

Job satisfaction has a strong relationship with OCB (Organ and Ryan, 1995). Employees will display more OCB behavior when they are satisfied with their work, satisfied with coworkers, support provided by the organization and coworkers (Bateman and Organ, 1983). Spector (1997) states that an employee who has a high job satisfaction rating correlates with positive OCB behavior, namely timely, altruism and compliance.

\section{Reseach Methods}

This research was conducted at a public hospital in Malang. The area is very wide and hospitals are generally very large, the technique of determining the location of the study uses cluster sampling so that public hospitals are available in Malang, Batu City and Malang District. the location of this study was RSSA, Persada Hospital RSUKH and RSI Madinah in Kasembon in Malang District.

The sample of this study was 175 nurses in the hospital with sampling techniques: proportional randem sampling. the main instrument in retrieving data is by using a questionnaire. the analysis technique used is descriptive analysis and inferential analysis using GSCA.

Table 1. Number of Samples and the Distribution in Hospital

\begin{tabular}{|c|c|c|c|}
\hline No & Hospital & Population & Sample \\
\hline 1 & $\begin{array}{l}\text { RSUD.Dr. Saiful } \\
\text { Anwar }\end{array}$ & 953 & $(953: 1235) \times 175=135$ \\
\hline 2 & Persada Hospital & 91 & $(91: 1235) \times 175=13$ \\
\hline 3 & $\begin{array}{l}\text { RSU. Karsa } \\
\text { Husada Batu }\end{array}$ & 137 & $(137: 1235) \times 175=19$ \\
\hline \multirow[t]{2}{*}{4} & $\begin{array}{l}\text { RSI Madinah } \\
\text { Kasembon }\end{array}$ & 54 & $(54: 1235) \times 175=8$ \\
\hline & Total & 1235 & 175 \\
\hline
\end{tabular}

Source: Processed data, 2018

Data analysis used in this study is descriptive analysis and inferential analysis to test hypotheses using GSCA.

The hypothesis model in this study can see in this figure below:

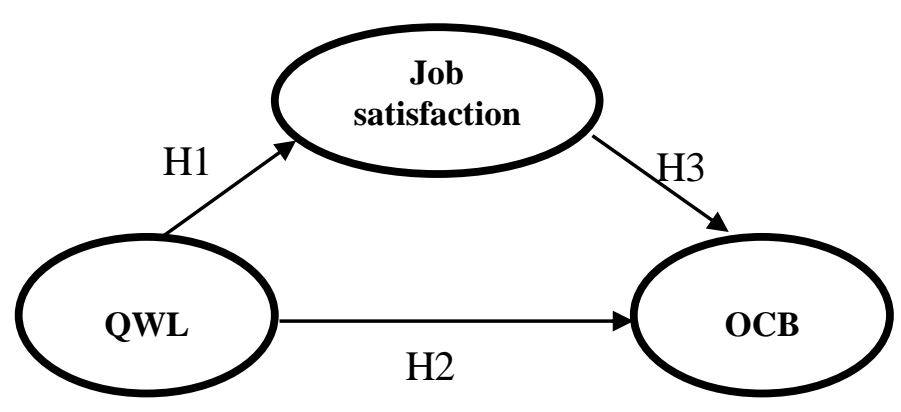

Figure 3.1. Hypothesis model

Source: Analytical result, 2018

Note:

H1: QWL has significant effect on job satisfaction

H2: QWL has significant effect on OCB

H3: job satisfaction has significan effect on OCB

\section{Results}

Data relating to respondents classified by sex/ gender, educational background, years of service and the field of service in the hospital. Based on respondents' data relating to gender, data were obtained that nurses who were female were 122 people $(70 \%)$ and those of male sex were 53 people (30\%). Based on the questionnaire that has been distributed, data is obtained about nurses' educational background, the majority of respondents with D3 education background are 124 respondents $(70.86 \%), \mathrm{S} 1$ education background with 44 
respondents $(25.14 \%)$, with a D4 education background of 6 respondents $(3.43 \%)$ and those with a $\mathrm{S} 2$ education background of 1 respondent $(0.57 \%)$

Respondents of this study had diverse ages, ranging from 22 years old (lowest age) to 59 years old (highest age). The majority of respondents were in the age range of 27-31 years as many as 62 respondents $(35.42 \%)$, as many as 26 respondents $(14.86 \%)$ had ages $22-26$ years and 32-36 years, as many as 19 respondents $(10,86 \%)$ have ages 37-41 years, as many as $18(10.29 \%)$ respondents have age $42-46$ years. There were 9 respondents $(5.14 \%)$ having ages $41-51$ and 52-56 years old and there were 6 respondents $(3.42 \%)$ who were 54 59 years old.

The respondent's data based on the working period obtained data that most respondents were in the working period $<1-5$ years as many as 87 respondents $(49.7 \%)$. A total of 27 respondents $(15.5 \%)$ had a working period of $6-10$ years. There were 20 respondents $(11.4 \%)$ having a working period of 11-15 years. Each of the 13 respondents $(7.4 \%)$ had a working period of $16-20$ years and 26-30 years. There were 8 respondents (4.6\%) who had a working period of 21-25 years. There are 6 respondents $(3.4 \%)$ who have a working period of 36-40 years and there is 1 respondent $(0.6 \%)$ who has a working period of 31-35 years

Data about respondent based on the part/ field of service provided, the majority of respondents provided services at inpatient services (IRNA) as many as 118 respondents $(67.43 \%), 53$ respondents $(30.29 \%)$ provided services to outpatient installations (IRJ) and each each of the 2 respondents (1.14\%) provided services in the ICU and operating room.

\subsection{Descriptive analysis}

The results of the descriptive analysis, the interpretation of the respondent's answers can be shown as follows.

The QWL variable in this study uses four indicators, namely compensation which includes fair and adequate compensation, indicators of work conditions, which include safe working conditions and a healthy physical environment, indicators of competency development which include promotion opportunities and the provision of information about promotions. Leadership indicators that include task-oriented and relationshiporiented leaders.

The results of descriptive analysis the QWL variables are shown in the table as follows:

Table 2. Respondent's answer description on QWL variables

\begin{tabular}{|c|c|c|c|c|c|c|c|}
\hline & & \multicolumn{5}{|c|}{ Respondent's answers } & \multirow{2}{*}{ mean } \\
\hline & & SS & $\mathbf{S}$ & $\mathbf{N} / \mathbf{R}$ & TS & STS & \\
\hline \multirow{2}{*}{ QWL1.1 } & $\mathrm{f}$ & 6 & 56 & 61 & 44 & 8 & \multirow{2}{*}{3.05} \\
\hline & $\%$ & $3.40 \%$ & $32.00 \%$ & $34.90 \%$ & $25.10 \%$ & $4.60 \%$ & \\
\hline \multirow{2}{*}{ QWL1.2 } & $\mathrm{f}$ & 4 & 63 & 57 & 44 & 7 & \multirow{2}{*}{3.07} \\
\hline & $\%$ & $2.30 \%$ & $36.00 \%$ & $32.60 \%$ & $25.10 \%$ & $4.00 \%$ & \\
\hline
\end{tabular}

\begin{tabular}{|c|c|c|c|c|c|c|c|}
\hline & & \multicolumn{5}{|c|}{ Respondent's answers } & mean \\
\hline \multicolumn{7}{|c|}{ Mean Indicator QWL1 } & 3.06 \\
\hline \multirow{2}{*}{ QWL2.1 } & $\mathrm{f}$ & 8 & 98 & 48 & 19 & 2 & \multirow{2}{*}{3.52} \\
\hline & $\%$ & $4.60 \%$ & $56.00 \%$ & $27.40 \%$ & $10.90 \%$ & $1.10 \%$ & \\
\hline \multirow{2}{*}{ QWL2.2 } & $\mathrm{f}$ & 6 & 72 & 66 & 28 & 3 & \multirow{2}{*}{3.29} \\
\hline & $\%$ & $3.40 \%$ & $41.10 \%$ & $37.70 \%$ & $16.00 \%$ & $1.70 \%$ & \\
\hline \multicolumn{7}{|c|}{ mean Indicator QWL2 } & 3.41 \\
\hline \multirow{2}{*}{ QWL3.1 } & $\mathrm{f}$ & 13 & 81 & 61 & 14 & 6 & \multirow{2}{*}{3.46} \\
\hline & $\%$ & $7.40 \%$ & $46.30 \%$ & $34.90 \%$ & $8.00 \%$ & $3.40 \%$ & \\
\hline \multirow{2}{*}{ QWL3.2 } & $\mathrm{f}$ & 14 & 91 & 53 & 12 & 5 & \multirow{2}{*}{3.55} \\
\hline & $\%$ & $8.00 \%$ & $52.00 \%$ & $30.30 \%$ & $6.90 \%$ & $2.90 \%$ & \\
\hline \multicolumn{7}{|c|}{ Mean Indicator QWL3 } & 3.51 \\
\hline \multirow{2}{*}{ QWL4.1 } & $\mathrm{f}$ & 8 & 85 & 63 & 16 & 3 & \multirow{2}{*}{3.45} \\
\hline & $\%$ & $4.60 \%$ & $48.60 \%$ & $36.00 \%$ & $9.10 \%$ & $1.70 \%$ & \\
\hline \multirow{2}{*}{ QWL4.2 } & f & 12 & 87 & 62 & 12 & 2 & \multirow{2}{*}{3.54} \\
\hline & $\%$ & $6.90 \%$ & $49.70 \%$ & $35.40 \%$ & $6.90 \%$ & $1.10 \%$ & \\
\hline \multicolumn{7}{|c|}{ Mean indicator QWL 4} & 3.50 \\
\hline \multicolumn{7}{|c|}{ Mean variable $Q W L$} & 3,37 \\
\hline
\end{tabular}

Job satisfaction variables in this study used 5 indicators, job satisfaction, satisfaction with payroll, satisfaction with promotion, satisfaction with supervision and satisfaction with coworkers. The results of the descriptive analysis are shown in the table as follows:

Table 3. Respondent's answer description on variable job satisfaction

\begin{tabular}{|c|c|c|c|c|c|c|c|}
\hline \multirow{2}{*}{ KK } & & \multicolumn{5}{|c|}{ Respondent's answers } & \multirow{2}{*}{ mean } \\
\hline & & SS & $\mathbf{S}$ & $\mathbf{N} / \mathbf{R}$ & TS & STS & \\
\hline \multirow{2}{*}{ KK1.1 } & $\mathrm{f}$ & 17 & 99 & 42 & 13 & 4 & \multirow{2}{*}{3.64} \\
\hline & $\%$ & $9.7 \%$ & $56.6 \%$ & $24.0 \%$ & $7.4 \%$ & $2.3 \%$ & \\
\hline \multirow{2}{*}{ KK1.2 } & $f$ & 21 & 98 & 48 & 6 & 2 & \multirow{2}{*}{3.74} \\
\hline & $\%$ & $12.0 \%$ & $56.0 \%$ & $27.4 \%$ & $3.4 \%$ & $1.1 \%$ & \\
\hline & & & & \multicolumn{3}{|c|}{ Mean indicator KK1 } & 3.69 \\
\hline \multirow{2}{*}{ KK2.1 } & $\mathrm{f}$ & 5 & 55 & 61 & 42 & 12 & \multirow{2}{*}{2.99} \\
\hline & $\%$ & $2.9 \%$ & $31,4 \%$ & $34,9 \%$ & $24.0 \%$ & $6.9 \%$ & \\
\hline \multirow{2}{*}{ KK2.2 } & $\mathrm{f}$ & 7 & 49 & 62 & 44 & 13 & \multirow{2}{*}{2.96} \\
\hline & $\%$ & $4.0 \%$ & $28.0 \%$ & $35.4 \%$ & $25.1 \%$ & $7.4 \%$ & \\
\hline & & & & Mean & indicat & KK2 & 2.97 \\
\hline \multirow{2}{*}{ KK3.1 } & $\mathrm{f}$ & 8 & 82 & 57 & 23 & 5 & \multirow{2}{*}{3.37} \\
\hline & $\%$ & $4.6 \%$ & $46.9 \%$ & $32.6 \%$ & $13.1 \%$ & $2.9 \%$ & \\
\hline \multirow{3}{*}{ KK3.2 } & $\mathrm{f}$ & 8 & 83 & 58 & 22 & 4 & \multirow{2}{*}{3.39} \\
\hline & $\%$ & $4.6 \%$ & $47.4 \%$ & $33.1 \%$ & $12.6 \%$ & $2.3 \%$ & \\
\hline & & & & Mean & Indicat & KK3 & 3.38 \\
\hline \multirow{2}{*}{ KK4.1 } & $\mathrm{f}$ & 8 & 91 & 59 & 14 & 3 & \multirow{2}{*}{3.50} \\
\hline & $\%$ & $4.6 \%$ & $52.0 \%$ & $33.7 \%$ & $8.0 \%$ & $1.7 \%$ & \\
\hline \multirow{2}{*}{ KK4.2 } & $\mathrm{f}$ & 12 & 103 & 50 & 7 & 3 & \multirow{2}{*}{3.65} \\
\hline & $\%$ & $6.9 \%$ & $58.9 \%$ & $28.6 \%$ & $4.0 \%$ & $1.7 \%$ & \\
\hline
\end{tabular}




\begin{tabular}{rrrrrrrr}
\hline \multicolumn{1}{r}{ KK } & \multicolumn{4}{c}{ Respondent's answers } & mean \\
\hline & & & \multicolumn{4}{c}{ Mean indicator KK4 } & $\mathbf{3 . 5 7}$ \\
& $\mathrm{f}$ & 12 & 113 & 43 & 6 & 1 & \\
KK5.1 & $\%$ & $6.9 \%$ & $64.6 \%$ & $24.6 \%$ & $3.4 \%$ & $0.6 \%$ & 3.74 \\
& $\%$ & &
\end{tabular}

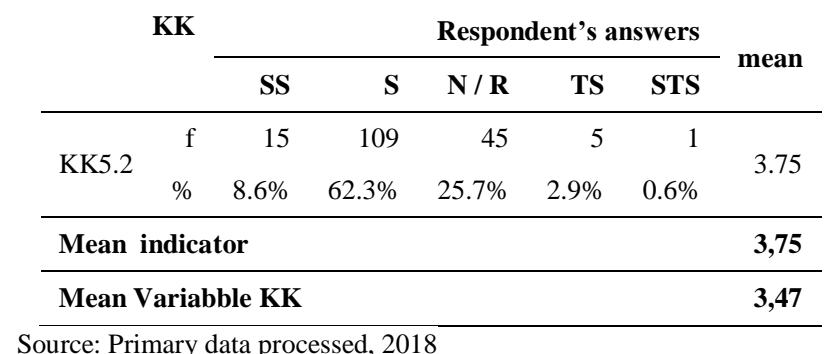

OCB variable in this study uses 5 indicators, namely altruism, civic virtue, concienciousness, courtesy, and sportmanship. Data from the descriptive analysis of OCB variables are shown in the table 4.

Table 4. Description of respondents' answers on OCB variables

\begin{tabular}{|c|c|c|c|c|c|c|c|}
\hline \multirow{2}{*}{ OCB } & & \multicolumn{5}{|c|}{ Respondent' $s$ anwers } & \multirow{2}{*}{ mean } \\
\hline & & SS & $\mathbf{S}$ & $\mathbf{N} / \mathbf{R}$ & TS & STS & \\
\hline \multirow{2}{*}{ OCB1.1 } & $\mathrm{f}$ & 15 & 125 & 33 & 2 & 0 & \multirow{2}{*}{3.87} \\
\hline & $\%$ & $8.6 \%$ & $71.4 \%$ & $18.9 \%$ & $1.1 \%$ & $0.0 \%$ & \\
\hline \multirow{2}{*}{ OCB1.2 } & $\mathrm{f}$ & 8 & 83 & 68 & 12 & 4 & \multirow{2}{*}{3.45} \\
\hline & $\%$ & $4.6 \%$ & $47.4 \%$ & $38.9 \%$ & $6.9 \%$ & $2.3 \%$ & \\
\hline \multicolumn{7}{|c|}{ Mean indicator OCB1 } & 3.66 \\
\hline \multirow{2}{*}{ OCB2.1 } & $\mathrm{f}$ & 16 & 85 & 67 & 7 & 0 & \multirow{2}{*}{3.63} \\
\hline & $\%$ & $9.1 \%$ & $48.6 \%$ & $38.3 \%$ & $4.0 \%$ & $0.0 \%$ & \\
\hline \multirow{2}{*}{ OCB2.2 } & $\mathrm{f}$ & 12 & 74 & 81 & 8 & 0 & \multirow{2}{*}{3.51} \\
\hline & $\%$ & $6.9 \%$ & $42.3 \%$ & $46.3 \%$ & $4.6 \%$ & $0.0 \%$ & \\
\hline \multicolumn{7}{|c|}{ Mean indicator OCB2 } & 3.57 \\
\hline \multirow{2}{*}{ OCB3.1 } & $\mathrm{f}$ & 18 & 105 & 49 & 3 & 0 & \multirow{2}{*}{3.79} \\
\hline & $\%$ & $10.3 \%$ & $60,0 \%$ & $28.2 \%$ & $1.7 \%$ & $0.0 \%$ & \\
\hline \multirow{2}{*}{ OCB3.2 } & $\mathrm{f}$ & 23 & 110 & 40 & 2 & 0 & \multirow{2}{*}{3.88} \\
\hline & $\%$ & $13.1 \%$ & $62.9 \%$ & $22.9 \%$ & $1.1 \%$ & $0.0 \%$ & \\
\hline \multicolumn{7}{|c|}{ Mean indicator OCB 3} & 3.83 \\
\hline \multirow{2}{*}{ OCB 4.1} & $\mathrm{f}$ & 28 & 116 & 27 & 3 & 1 & \multirow{2}{*}{3.95} \\
\hline & $\%$ & $16.0 \%$ & $66.3 \%$ & $15.4 \%$ & $1.7 \%$ & $0.6 \%$ & \\
\hline \multirow{2}{*}{ OCB 4.2} & $\mathrm{f}$ & 39 & 107 & 24 & 5 & 0 & \multirow{2}{*}{4.03} \\
\hline & $\%$ & $22.3 \%$ & $61.1 \%$ & $13.7 \%$ & $2.9 \%$ & $0.0 \%$ & \\
\hline \multicolumn{7}{|c|}{ Mean Indicator $O C B 4$} & 3.99 \\
\hline \multirow{2}{*}{ OCB5.1 } & $\mathrm{f}$ & 17 & 113 & 44 & 1 & 0 & \multirow{2}{*}{3.83} \\
\hline & $\%$ & $9.7 \%$ & $64.6 \%$ & $25.1 \%$ & $0.6 \%$ & $0.0 \%$ & \\
\hline \multirow{2}{*}{ OCB5.2 } & $\mathrm{f}$ & 12 & 97 & 62 & 3 & 1 & \multirow{2}{*}{3.66} \\
\hline & $\%$ & $6.9 \%$ & $55.4 \%$ & $35.4 \%$ & $1.7 \%$ & $0.6 \%$ & \\
\hline \multicolumn{7}{|c|}{ Mean indicator $O C B 5$} & 3,75 \\
\hline \multicolumn{7}{|c|}{ Mean variable $O C B$} & 3,76 \\
\hline
\end{tabular}

Source: Primary data processed, 2018

\subsection{Inferential analysis}

The result of inferential analysis to test hypotheses using GSCA the following results are obtained:

Table 5. Results of hypothesis testing

\begin{tabular}{lllllll}
\hline & Exogenous & Endogenous & $\begin{array}{c}\text { Path } \\
\text { Coefficients }\end{array}$ & SE & CR & Des. \\
\cline { 2 - 7 } H1 & QWL & JS & 0,795 & 0,043 & $18,459^{*}$ & Significant \\
H2 & QWL & OCB & 0.059 & 0,071 & 0,831 & $\begin{array}{l}\text { Not } \\
\text { significant } \\
\text { significant }\end{array}$ \\
H3 & JS & OCB & 0,236 & 0,077 & $3,082^{*}$ & signicing
\end{tabular}

Source: Primary data processed, 2018

Note: $*=$ significant at $\alpha 5 \%$

\subsubsection{The effect of $Q W L$ on job satisfaction}

The influence of Quality of Work Life on job satisfaction produces a critical ratio (CR) of $18.459 *$. This shows that the critical ratio value is asterisked (CR $\geq \mathrm{t}$-table $=2.00$ ). Therefore, it can be interpreted that there is a significant effect of Quality of Work Life on job satisfaction. The effect of QWL on job satisfaction is $0.795(79.5 \%)$. Based on the value of 0.795 , it can be interpreted that QWL through indicators of compensation, working conditions, development of competencies and leadership styles have a significant effect on job satisfaction.

The results of this study support the opinion of Walton (1975) and Ruzevicius (2007). QWL affects employee satisfaction employees who can produce high QWL will be more productive and effective, because the QWL program can improve employee morale and organizational effectiveness (Tabassum, 2012). The results of this study also correspond with the research conducted by Sirgy (2001), Saad et al. (2008), Muftah and Lafi (2011), Hasanmoradi (2011), Tabassum (2012), Gayathiri and Ramakrishnan (2013), where QWL has a positive and significant effect on job satisfaction.

\subsubsection{The effect of $Q W L$ on $O C B$}

The effect of Quality of Work Life on Organizational Citizenship Behavior results in a critical ratio (CR) of 0.831 . This shows that the value of the critical ratio is not marked with an asterisk $(\mathrm{CR}<\mathrm{t}$-table $=2.00)$. Therefore, it can be interpreted that there is no significant effect of Quality of Work Life on Organizational Citizenship Behavior. the effect is 0.059 . The effect is very small (5.9\%).

High QWL is very important for organizations to attract and retain workers (Kasraei, et al., 2014). The results of this study are not in accordance with previous studies by Sofiah et al. (2014), Kashani (2012), Nair (2013), Tehran et al. (2013) and Kasraie et al. (2014). The results show the influence of QWL on OCB. This research shows different results from the previous research, namely: there is no significant effect of QWL on OCB.

QWL will have a positive and significant effect when mediated by job satisfaction of $0.188 *$. This shows that 
the better the job satisfaction caused by the better QWL, the tendency to increase OCB nurses. Based on the findings of the study, QWL did not significantly influence OCB nurses. In order to increase nurses 'OCB, nurses' QWL must also be improved, so that nurses will also be satisfied so that OCB nurses will also increase

\subsubsection{The effect job satisfaction on $O C B$}

The effect of job satisfaction on Organizational Citizenship Behavior produces a critical ratio (CR) of $9,188 *$. This shows that the critical ratio value is asterisked $(\mathrm{CR} \geq \mathrm{t}$-table $=2.00)$. Therefore, it can be interpreted that there is a significant effect of job satisfaction on Organizational Citizenship Behavior.

The results of this study are in accordance with the opinion (Organ and Ryan, 1995) which states that job satisfaction has a strong relationship with OCB. Employees will display more OCB behavior when they are satisfied with their work, satisfied with coworkers, support provided by the organization and coworkers (Bateman and Organ, 1983). Spector (1997) states that an employee who has a high job satisfaction rating correlates with positive OCB behavior, namely timely, altruism and compliance.

This results of this study are support the research conducted by Bateman and Organ, 1983; Shokrkon and Naami, 2009; Arif and Chohan, 2012; Swaminathan and Jawahar, 2013 which states that there is a strong and positive relationship between job satisfaction and OCB. The results of this study are not in accordance with the results of a study conducted by Mehboob and Bhutto (2012) which showed the results of work satisfaction research were very weak predictors of OCB and only partially affected the OCB dimension.

\section{Discussion and Conclusion}

In this study we examine the effect of quality of work life on job satisfaction and organization citizenship behavior. We use case of nurses at numeraous hospital in Malang regency Indonesia. The indicators used to measure QWL are: compensation, working conditions, competency development and leadership. The indicator that gives the biggest contribution to the QWL variable is competency development, and the lowest is working conditions. Therefore, for the next researcher, they can consider two indicators to be retested whether the results will be the same or different. The results of hypothesis testing about the effect of QWL on OCB showed that there was no significant effect between QWL and OCB. Based on the results of the indirect test produced a positive and significant effect of QWL on OCB through job satisfaction.

The results of the research for the QWL variable, the indicator that has the highest weight value is the competency development indicator with a value of 0.617. Therefore to further improve QWL nurses can further enhance the development of nurse competencies by providing more opportunities to develop careers and to further improve nurse skills/ skills in addition to increasing nurses compensation, creating safe and healthy working conditions, and applying leadership styles that apply leadership style

For the variable job satisfaction, based on the results of descriptive analysis shows the results that nurse job satisfaction is good. Therefore the hospital must further improve nurse job satisfaction. Indicators that have a large value are satisfaction with payroll and satisfaction with promotion. Therefore the hospital can further improve nurse job satisfaction related to payroll and promotion, in addition to increasing satisfaction with work, satisfaction with superiors and satisfaction towards colleagues.

The OCB variable based on the results of the descriptive analysis showed that nurses' OCB was good/ high, therefore it was further improved. The indicator that has the greatest value is civic virtue, which is to further enhance the feeling of being proud of being part of the hospital and increasing the activeness of nurses in following developments and information about the hospital. Other indicators also need to be emphasized such as altruism, conscientiousness, courtesy and sportsmanship.

There is a significant association of QWL on job satisfaction. The effect is positive and significant, this means that the better QWL tends to increase nurse job satisfaction. The results of this study support the results of research conducted by Lewis (2001), Sirgy (2001), Saad (2008), Muftah and Lafi (2008), Hasanmoradi (2011), Tabassum (2012), Gayathiri et al. (2013) Rubel and Kee (2014) which states that there is a significant effect of QWL on job satisfaction.

There is no significant association of QWL on OCB. The effect of QWL on OCB is positive and not significant, this means that the better QWL tends to increase OCB, even though the increase is not significant. The results of this study do not support / differ from the results of research conducted by Kashani (2012), Nair (2013), Neeta (2013) and Kasraie (2014) which state that there is a significant influence/ relationship between QWL and OCB.

There is a significant association of job satisfaction on OCB. this states that job satisfaction has a positive and significant effect on OCB, which shows that better job satisfaction tends to increase OCB. The results of this study support the results of research conducted by Shokrhon and Naami (2009), Mohammad et al. (1011), Arif \& Chohan (2012), Menhoob \& Bhutto (2012), Unal (2013), and Swaminathan \& Jawahar (2013) which stated that there was a significant effect of job satisfaction on OCB.

This study has several limitations that we will suggest for future studies. First, limitations when the data collection process is the respondents in this study are nurses, while nurses have tasks that sometimes cannot be handled, so that in distributing questionnaires must be left first. In distributing the questionnaire it cannot be pure random, because it depends on the boss/ head of the room. 
Second, it is very difficult to find data in detail, because research in the hospital has procedures that must be passed. There is some data needed as a supplement for analysis purposes, but not provided by the hospital. Such as data relating to compensation.

Third, in this study the main instrument in data collection is a questionnaire. So the results cannot dig deeper in relation to the variables under study. For future studies, it is recommended to be able to explore data by interviewing key informants.

\section{References}

Arif, A \& Chohan, A. (2012). How Job Satisfaction is Influencing the Organization Citizenship Behavior (OCB): a Study on Employees Working in Bangking Sector of Pakistan. ijcrb.webs.com. Interdisciplinary Journal of Contemporary Reseach in Business. December, 4(8).

Bateman, T. S., \& Organ., D. W. (1983). Job Satisfaction and the Good Soldier: the relatioship between affect and employee citizenship. The Academy of Management Journal, 26 (4), 587595

Evans, L. (2001). Delving deeper into morale, job satisfaction and motivation among education professionals: re-examining the leadership dimension'. Educational Management \& Administration, 29 (3), 291-306

Gayathiri, R. \& Ramakrishnan, L. (2013). Quality of Work Life - Linkage with Job Satisfaction and Performance. International Journal of Business and Management Invention, 2(1) pp. 01-08.

Hasanmoradi, N. (2011). Relationship between The Quality of Work Life and Job Satisfaction among The Teachers of Public and Non -Public School in Tehran. International Journal of Arts \& Sciences, 4(25), 279-285.

Ivancevich, J.M. Kanopaske, R \& Matterson, M. T. (2007). Organizational Behavior and Management. Seven Edition. McGraw-Hill: New York.

Kashani, F.H. (2012). A Review on Relationship between Quality of Work Life and Organizational Citizenship Behavior (Case Study: An Iranian Company). J. Basic. Appl. Sci. Res., 2(9)95239531.

Kasraie, S., Parsa, S., Hassani, M, \& Zadeh, A.G. (2014). The Relationship between Quality of Work Life, Job Stress, Job Satisfaction and Citizenship Behavior in Oshnaviyeh Hospital's Staff. Patient Safety \& Quality Improvement Journal, 2(1) pp. 1-5.

Lewis, D., Brazil, K., Krueger, P., Lohfeld, L. \& Tjam, E. 2001. Extrinsic and Intrinsic Determinants of Quality of Work Life. Leadership in Health Service, 14(2) pp. 9-15.

Locke, E.A. (1976). The Nature and Causes of Job Satisfaction in M. D. Dunnette, Handbook of Industrial and Organizational Psychology,
Chicago: Rand McNally College Publishing Company: pp. 1297-1349.

Majbel, A.A, Almsafir, M.K., Siron, R.S. \& Alnaser, A.S. (2013). The Drivers of Quality of Working Life (QWL): A Critical Review. Australian Journal of Basic and Applied Sciences, 7(10) pp. 398-405.

Mohammad, J., Habib, F.Q. \& Alias, M.A. (2011). Job Satisfaction and Organization Citizenship Behavior: An Empirical Study at Higher Learning Institution. Asian Academy of Management Journal, 16(2) pp. 149-165.

Muftah, H.A. \& Lafi, H. (2011). Impact of QWL on employee satisfaction case of oil and gas industry in Qatar. Advances in Management \& Applied Economics, vol.1, no.2, 2011, 107-134. ISSN: 1792-7544 (print version), 1792-7552 (online) .International Scientific Press, 2011

Murthy, R.K. (2014). Self-Efficacy, Work Engagement and Organizational Commitment . Global Journal of Multidisciplinary Studies, 3(6).

Nanjundeswaraswamy, T.S, \& Swamy, D.R. (2013). Review of Literature on Quality of Work Life. International Journal for Quality Research, 7(2).

Neeta, B. (2013). Organizational Citizenship Behavior of Faculties in Private Engineering Colleges W.E.F Lucknow. IJMBS, 1(3).

Organ, DW.(1988). Organizational Citizenship Behavior: The Good Soldier Syndrome. Lexington, MA: Lexington Books.

Organ, D. W. \& Ryan, K. (1995). A Meta-Analytic Review of Attitudinal and Dispositional Predictors of Organizational Citizenship Behaviol. Personnel Psychology, 48(1) pp. 775802

Spector, P. (1997). Job Satisfaction: Application, Assesment, Causes, and Consequences. Thousand Oaks, CA: Sage Publications

Sundaray, B.K., Sahoo, C.K. \& Tripathy, S.K. (2013). Impact of Human Resource Interventions on Quality of Work Life: An Exploration. International Employment Relations Review, 19(1) pp. 68-86.

Swaminathan, S. \& Jawahar, P. D. (2013). Job Satisfaction as predictor of Organization Citizenship Behavior: An Empirical Study. Global Journal Of Business Reseach, 7(1).

Tabassum, A. (2012). Interrelations between Quality of Work Life Dimensions and Faculty Member Job Satisfaction in the Private Universities of Bangladesh. European Journal of Business and Management, 4(2).

Tehran, G.M., Abtahi, M.S. \& Esmaeili, S. (2013). The Relationship between Organizational Citizenship Behavior and Performance of the Staff of Qazvin University of Medical Sciences and Health Services. International Journal of Academic Research in Business and Social Sciences, (3)9 pp. 2222-6990

Unal, O.F. (2013). Relationship between The Facets of Job Satisfaction and The Dimensions of Organization Citizenship Behavior: Mediating Role Of Organization Commitmen. Suleyman Demirel University. The Journal of Faculty of 
Economics and Administrative Sciences, 18(1) pp. 243-269.

Walton, R.A. 1973. Quality of Work Life: What is it? Sloan Management Review, Fall, pp. 11-21. 